\title{
Pengaruh Penggunaan Kaporit Sebagai Desinfektan Terhadap Daya Aroma Pakan Pada Budidaya Udang Windu (Penaeus monodon Fabricius)
}

\author{
Suryono 1*, Edi Wibowo', Ria Azizah TN1, R Ario' dan Gentur Handoyo² \\ 'Departemen IImu Kelautan, Fakultas Perikanan dan IImu Kelautan, Universitas Diponegoro \\ 2Departemen Oseanografi, Fakultas Perikanan dan Ilmu Kelautan, Universitas Diponegoro \\ JI. Prof. Soedarto, SH. Kampus UNDIP Tembalang, Semarang 50275 \\ Email : suryono1960@gmail.com
}

\begin{abstract}
Tiger prawn (Penaeus monodon Fabricius) is one of very ideal species of crustacean to be cultivated. This is due to its growth is very quickly, highly survival rate, easy to live in compartement, and its also very acceptable by local and international market. In order to increase production of cultivation, therefore caporit was applicated as disinfectant in cultivation in order to reduce virus and bactery which couse of diseases. However to date, the impact of the use of kaporit has not yet been known on food attractant degradation. The aim of this research was to know effect of the use of caporit on food attractant by the prawn. Research was conducted in Marine Station Teluk Awur, Jepara. Faculty of Fishery and Marine Science Diponegoro University. The method of this research was ekperimental Laboratory by using complete randomly design (RAL) with four treatments and three replication, concentration kaporit 0 ppm as control (K1) 2 ppm (K2), $4 \mathrm{ppm}$ ( K3) and $6 \mathrm{ppm}$ ( K4)., respectively. Data obtained was tested by F test ( Anova)The Results showed that food attractant of control treatment (K1) is 53,68, K2 ( 2 ppm) is 285,25, K3 ( 4 ppm) is]364,59 and K4 ( 6 ppm) is]373,37 seconds. The Results of statistical analysis confirmed that the use of kaporit have an effect on food attractant $(P<0.05)$. However, continued test by BNT shows that only control gave significant different to the treatment, but within threatment was not give significant different.
\end{abstract}

Keywords : Tiger Prwan, Disinfectant, Caporit, attracted Food

\begin{abstract}
Abstrak
Udang windu (Penaeus monodon Fabricius) merupakan salah satu spesies crstacea yang ideal untuk dibudidayakan. Hal ini dikarenakan pertumbuhannya yang cepat, derajad kelulus hidupannya yang tinggi, tahan hidup dalam tempat pemeliharaan, serta sangat digemari oleh konsumen dalam dan luar negeri. Guna peningkatan produksi dalam budidaya maka digunakan kaporit sebagai disinfektan pada media air budidaya guna pengendalian bakteri dan virus sebagai penyebab munculnya penyakit. Namun sampai saat ini belum diketahui dampak penggunaan kaporit terhadap penurunan daya aroma pakan yang diberikan. Tujuan dari penelitian ini adalah guna mengetahui pengaruh penggunaan kaporit terhadap daya tarik udang pada pakan yang diberikan. Penelitian dilaksanakan di Marine Station Teluk Awur, Jepara. Fakultas Perikanan dan IImu Kelautan Universitas Diponegoro. Metode yang dipergunakan dalam penelitian ini adalah metode ekperimental dengan menggunakan rancangan acak lengkap (RAL). Perlakuan yang diujikan yaitu empat perlakuan terdiri dari konsentrasi kaporit 0 ppm (K1) sebagaai perlakukan kontrol, dan 2 ppm (K2), 4 ppm (K3) serta 6 ppm (K4) sebagai perlakukan utama. Data yang diperoleh selanjutnya dilakukan uji $F$ (Anova). Hasil penelitian menunjukan bahwa daya Tarik udang terhadap pakan yang diberikan pada perlakukan kontrol (0 ppm) (K1) adalah 53,68, detik, K2 ( 2 ppm) adalah 285,25 detik, K3 (4 ppm) adalah 364,59 detik dan K4 (6 ppm) adalah 373,37 detik. Hasil analisis ragam menunjukan
\end{abstract}


bahwa penggunaan kaporit berpengaruh terhadap daya aroma pakan $(P<0.05)$. Uji lanjut BNT menunjukan bahwa perlakukan Kontrol berbeda sangat nyata $(P<0.001)$ terhadap perlakuan yang dicobakan, tetapi antar perlakukan tidak menunjukan perbedaan nyata satu terhadap yang lain.

Kata Kunci : Udang windu, Kaporit, Disinfektan, dan Daya Aroma

\section{PENDAHULUAN}

Sampai saat ini udang windu merupakan salah satu jenis organisme laut yang ideal untuk dibudidayakan dikarenakan keunggulan sifat biologis yang dimiliki, yaitu : pertumbuhannya cepat, derajat kehidupan yang tinggi, tahan hidup dalam sistem pemeliharaan, dan digemari oleh konsumen.Dalam budidaya udang, ketersediaan pakan tambahan (pakan buatan) yaitu mencapai 90 - $1000 \%$ (Rachmatun, 1991). Ketersediaan pakan tersebut bukan saja dari segi kuantitas tetapi juga dari segi kualitas. Kualitas pakan buatan ditentukan oleh kandungan gizi, kesetabilan fisik didalam air, kemudahan dicerna, aroma dan rasa. Selanjutnya diketahui bahwa aroma dan rasa merupakan dua faktor yang menentukan kualitas dari sebuah pakan buatan. Hal ini dikarenakan pakan dengan kandungan nutrisi yang bagus apapun menjadi tidak berarti apabila tidak dapat dimakan oleh udang yang dipelihara.

Udang yang dipelihara mengetahui kualitas pakan melalui aroma dan rasa. Oleh karena itu pakan udang harus memiliki aroma dan rasa yang disukai oleh udang (Akiyama dan Chuang, 1991).Permasalahan muncul, ketika dalam sistem budidaya memerlukan managemen kualitas air. Guna menjaga kualitas air dipergunakan kaporit (Kokarkin, 2001), sehingga diduga berpengaruh terhadap daya aroma pakan yang diberikan kepada organisme yang dibudidayakan. Sampai saat ini belum tersedia data yang akurat tentang dampak pemberian kaporit dalam pengelolaan air terhadap penurunan daya aroma pakan sehingga berpengaruh terhadap ketertarikan udang terhadap pakan yang diberikan. Penggunaan kaporit pada media hidup udang yang dipelihara akan mengakibatkan kemampuan biologi udang guna membau rangsang aroma pakan akan berkurang pada level tertentu. Oleh karena itu maka diperlukan penelitian guna mengetahui dampak penggunaan kaporit dalam berbagai dosis terhadap penurunan daya aroma pakan udang windu (P. monodon). Bagan alur penelitian dapat dilihat pada Gambar 1.

\section{MATERI DAN METODE}

Biota yang dipergunakan dalam penelitian ini adalah tokolan udang windu PL 50 dengan berat 0,7 - 0,8 gram sebanyak 400 ekor yang didapat dari BBPBAP Jepara, Kementrian Kelautan dan Perikanan. Bahan uji yang dipergunakan adalah pakan buatan jenis "CP Prawn Feed" produksi PT proteina prima Surabaya. Sedangkan kaporit sebagai perlaukuan yang diujikan adalah kaporit teknis yang diproduksi oleh PT Tjiwi Kimia Semarang

Metode Penelitian yang digunakan adalah metode eksperimen laboratorium. Rancangan percobaan yang yang dipergunakan adalah Rancangan Acak Lengkap (RAL) dengan 4 perlakukan dan 3 kali ulangan. Perlakukan yang diujikan adalah 0 ppm (kontrol), 2 ppm, 4 ppm, dan $6 \mathrm{ppm}$. Hal ini sesuai dengan pendapat Kokarkin (2001) yang menyatakan bahwa konsentrasi $3-5$ ppm adalah konsentasi maksimal kaporit yang dapat berfungsi sebagai disinfektan di tambak.

Udang windu yang terseleksi sebagi hewan uji dimasukan dalam akuarium yang telah diberi perlakukan konsentrasi kaporit 0 ppm,2 ppm ,4 ppm, dan 6 ppm. Selanjutnya pakan yang diberikan dimasukan kedalam akuarium, kemudian dilakukan pencatatan waktu yang dipergukan hewan uji melakukan pergerakan mendekati dan menangkap pakan. (Akiyama dan Chuang, (1991). Bersamaan dengan waktu 


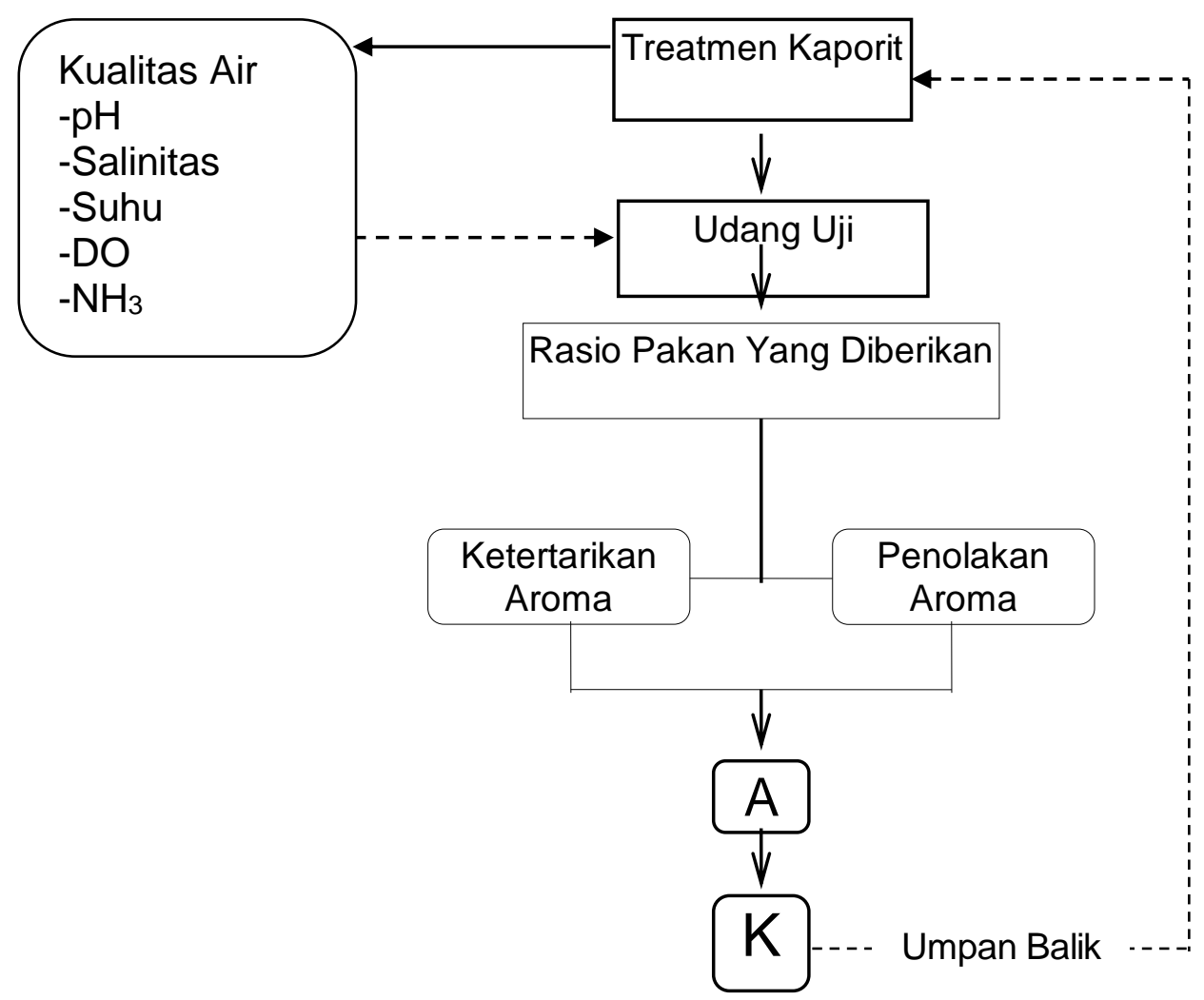

Gambar 1. Alur Penelitian

pengamatan dilakukan pengukuran kualitas air yaitu $\mathrm{pH}$, suhu, salinitas, dan DO. Data yang diperoleh dari hasil ujicoba dianalisa dengan analisi sidik ragam (ANOVA)(Heryanto, 1996).

\section{HASIL DAN PEMBAHASAN}

Dari penelitian yang dilakukan, diperoleh data ketertarikan pakan pada udang windu ( Penaeus monodon Fab ) seperti yang disajikan pada Tabel 1. Ketertarikan pakan udang windu setelah diadakan pengamatan dengan diberi perlakuan konsentrasi kaporit yang berbeda, yaitu : 0 ppm (K1). 2 ppm (K2), 4 ppm (K3), 6 ppm (K4) mempunyai nilai rataan berturut-turut adalah : 53.68; 285.25; 364.59; 373.37 detik. Grafik ketertarikan pakan udang windu untuk tiap-tiap perlakuan disajikan pada Gambar 2.

Dari Tabel 1. dan Gambar 2. terlihat bahwa ada perbedaan waktu ketertarikan udang terhadap pakan yang diberikan dikarenakan perlakukan yang dicobakan. Selanjutnya guna melihat adanya perbedaan antar perlakuan maka dilakukan uji statistik. Dari uji ANNOVA diketahui bahwa perlakuan yang diuji cobakan mempunyai pengaruh berbeda nyata $(P>0,05)$

Selanjutnya guna mengetahui perbedaan antar perlakukan dilakukan uji lanjutan dengan menggunakan uji BNT (Sriandono, 1987). Hasil perhitungan uji BNT disajikan pada Tabel 4. Hasil yang diperoleh menunjukan bahwa seluruh perlakuan berbeda nyata dengan kontrol sedangkan antar perlakukan $\mathrm{K} 2, \mathrm{~K} 3$ dan K4 saling tidak berbeda nyata.

Hasil penelitian menunjukan bahwa perlakukan konsentrasi kaporit yang berbeda memberikan perbedaan terhadap waktu ketertarikan udang windu terhadap paklan yang diberikan $(P>0,05)$. Hal ini sesuai dengan pendapat Waterman (1961) bahwa stimultan atau rangsangan bahan kimia dapat menunjukan pengaruh terhadap beberapa aktivitas atau perilaku udang seperti mencari pakan, makan, kawin dan 
Tabel 1. Hasil pengamatan pengaruh konsentrasi kaporit terhadap ketertarikan pakan pada udang windu (detik)

\begin{tabular}{ccccc}
\hline Ulangan & \multicolumn{4}{c}{ Perlakuan $(\mathrm{ppm})$} \\
\cline { 2 - 5 } & 0 & 2 & 4 & 6 \\
\hline 1 & 35,85 & 180,30 & 299,83 & 316,75 \\
2 & 60,05 & 205,57 & 327,81 & 371,40 \\
3 & 65,16 & 282,15 & 466,13 & 431,98 \\
Rerata $(x)$ & 53,68 & 285,25 & 364,59 & 373,37 \\
SD & 22,14 & 81,28 & 89,04 & 57,64 \\
\hline
\end{tabular}

\section{Ketertarikan Pakan}

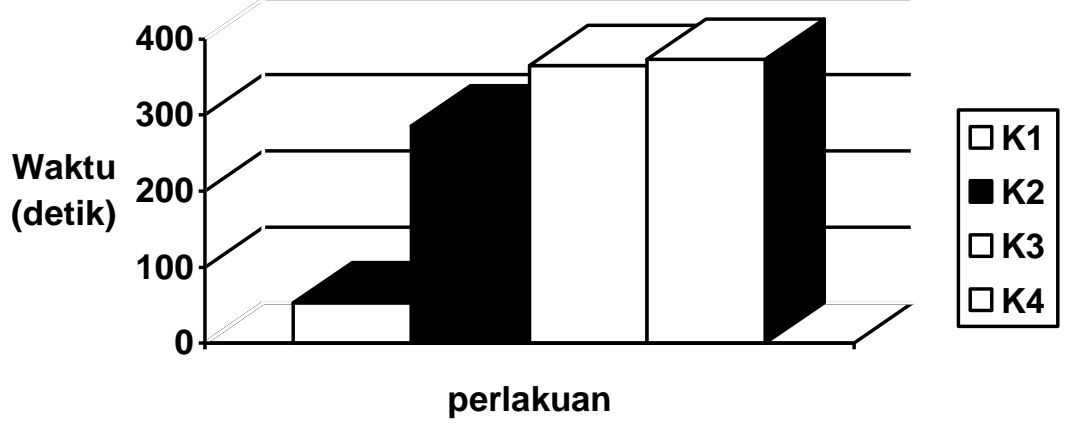

Gambar 2. Daya tarik Udang windu Pada Pakan (detik) Pada Konsentrasi Kaporit Yang Berbeda

Tabel 2. Uji BNT Waktu Ketertarikan Udang Windu Terhadap Pakan

\begin{tabular}{ccccc}
\hline Perlakuan & Rerata & K1 & K2 & K3 \\
\hline K1 & 53,68 & & - & - \\
K2 & 282,25 & $231,57^{* *}$ & - & - \\
K3 & 364,59 & $310,91^{* *}$ & 79,34 & - \\
K4 & 373,37 & $319,69^{* *}$ & 88,12 & 8,78 \\
\hline
\end{tabular}

Keterangan :** Berbeda sangat nyata

migrasi. Hal ini dikarenakan udang dalam menemukan makananya melalui alat penciumannya (Chemosensory), bukan melalui penglihatannya (Haerudin, 1993)

Hasil uji BNJ menunjukan bahwa perlakukan $\mathrm{K} 1$ berbeda sangat nyata terhadap perlakuikan K2, K3, dan K4. Antar perlakukan K2, K3, dan K4 tidak berbeda nyata (Tabel 2). Hal ini diduga dikarenakan perlakukan kaporit yang diberikan kurang lebar daya rentang level konsentrasinya sehingga tidak memberikan perbedaan yang nyata, tetapi apabila dibandingkan dengan kontrol maka sangat berbeda nyata. Selain itu diduga karena sifat kaporit yang tidak stabil didalam air sehingga kadarnya akan turun dengan cepat yang disebabkan oleh sinar mata hari, lampu listrik atau pengocokan (Alerts dan Santika, 1984).

Hasil pengkuran terhadap parameter kualitas air adalah sebagai berikut : salinitas berkisar antara 29- 30 ppt, suhu berkisar antara $30-32 \circ \mathrm{C}, \mathrm{pH}$ air berkisar antara $7-7,2$, sedangkan oksigen 
terlarut berkisar antara $6-6,4$ ppm. Hasil tersebut menunjukan bahwa kualitas air pada media penelitian masih berada pada kisaran yang layak untuk hidup udang windu. Dengan demikian dapat dikatakan bahwa selama penelitian parameter kualitas air masih dalam kondisi optimal untuk menunjang pelaksanaan penelitian yang dilakukan.

\section{KESIMPULAN}

Dari hasil pengamatan perlakukan konsentrasi kaporit yang berbeda dapat disimpulkan bahwa, pemberian kaporit dengan konsentrasi yang berbeda memberikan pengaruh yang nyata terhadap daya tarik udang terhadap pakan yang diberikan. Kisaran parameter kualitas air masih dalam batas toleransi daya hidup udang selama penelitian.

\section{DAFTAR PUSTAKA}

Akiyama D.M \& Chuang, L.M.N., 1991. prinsip Pengelolaan Udang. Technical
Bulletin. American Soy Bean Association. Singapore.175 pp.

Alerts, G. \& Santika, S.S. 1984. Metode penelitian Air. Penerbit Usaha Nasional. Surabaya. HIm : $103-112$

Haerudin. 1993. Bertambak Udang Windu Secara Intensif. Undip. Semarang. 51 Halaman.

Heryanto, E. 1996. Rancangan Percobaan pada Bidang Pertanian. PT Trubus Agriwidya. Ungaran.

Kokarkin, C. 2001. Sistem Pengelolaan Budidaya Udang Wundu Tingkat Sederhana Dan Semi Intensif Yang Sesuai Dengan Syarat Pasar Dunia. BBPAP. Jepara $4 \mathrm{HIm}$.

Rachmatun, M.S. 1991. Semi Intensif Prawn Culture. BBAP. Jepara

Sriandono, B.1987. Rancaanan Percobaan. Diktat kuliah. Fakultas Peternakan Undip.

Waterman, T. 1961. Physiology Of Crustacea. Vol.7 . (Sense Organ And Behaviour) Academic Press. New York. 